EWA ROJEWSKA

ORCID 0000-0003-3988-810X

Uniwersytet Szczeciński

\title{
O STRESIE \\ W RÓŻNORODNYCH PRZESTRZENIACH ŻYCIOWYCH NASTOLATKÓW W KONTEKŚCIE ICH SEKSUALNOŚCI
}

\begin{abstract}
AвSTRAct. Rojewska Ewa, O stresie w różnorodnych przestrzeniach życiowych nastolatków w kontekście ich seksualności [On Adolescents' Stress in Various Areas of Life in the Context of their Sexuality]. Studia Edukacyjne nr 59, 2020, Poznań 2020, pp. 249-271. Adam Mickiewicz University Press. ISSN 12336688. DOI: $10.14746 /$ se.2020.59.16
\end{abstract}

Bearing in mind the meaning of sexuality for the quality of human life, adolescence as a vulnerable period and the attendant risks, the main issue of interest in this text is stress in various areas of life of adolescents in the context of their sexuality. The first part of the article focuses on young people's sexuality on the basis of relevant literature, while the further part of the study presents methodological assumptions. The third part of the work is dedicated to the analysis of the examination results. The article ends with the conclusions made on the basis of the research results.

Key words: stress, adolescents, young people's sexuality, sexual growth

\section{Wprowadzenie}

Seksualność młodzieży jest współcześnie szeroko komentowana. Głos $\mathrm{w}$ dyskusji zabierają $\mathrm{w}$ niej tak publicyści, politycy, naukowcy, jak i rodzice zatroskani o przyszłość oraz teraźniejszość swoich dzieci. Niejednokrotnie dyskusje te mają charakter ideologiczny i zawierają w sobie dużą dozę emocji. Ze względu na fakt, że istotnie jakość wychowania seksualnego i jakość realizacji seksualności ma ogromne znaczenie dla całego życia człowieka, warto podejmować namysł naukowy nad tą sferą życia, aby zgłębiać o niej wiedzę i wypracowywać wynikające z niej praktyczne implikacje.

Nadto, warto zaznaczyć, że ponowoczesna rzeczywistość funkcjonowania młodzieży niesie ze sobą wiele wyzwań i zagrożeń. Obrazować ten 
fakt może na przykład rosnąca liczba dzieci i młodzieży doświadczających różnego rodzaju zaburzeń psychicznych. Szacuje się, że około 10-20\% dzieci i młodzieży doświadcza tego rodzaju zaburzeń ${ }^{1}$. Można przyjąć hipotezę, że ma to związek między innymi z doświadczaniem różnorodnego stresu, choć oczywiście nie tylko. UNICEF wśród pięciu grup umiejętności życiowych ważnych dla budowania dobrostanu psychicznego wymienia radzenie sobie i kierowanie stresem, czego przykładami są radzenie sobie z presją i sytuacjami trudnymi, samokontrola, czy też poszukanie pomocy i wsparcia². Psychologowie zwracają uwagę, że współcześnie tak dzieci, jak i młodzież oraz osoby dorosłe narażeni są na działanie wielu stresorów, co może przyczyniać się do długofalowych negatywnych skutków dla jakości życia.

Dostrzegając znaczenie seksualności dla jakości życia człowieka, adolescencji jako newralgicznego okresu życia w tym aspekcie oraz zagrożenia z nimi związane, przedmiotem zainteresowania w niniejszym tekście uczyniono stres w różnorodnych przestrzeniach życiowych nastolatków w kontekście ich seksualności. W pierwszej części artykułu przedstawiono seksualność młodzieży oraz stres w świetle literatury przedmiotów. W dalszej części pracy przedłożone zostały założenia metodologiczne przeprowadzonych badań. Trzecia część pracy poświęcona jest analizie pozyskanych wyników badań. Pracę wieńczą wnioski płynące z uzyskanych rezultatów badawczych.

\section{Seksualność młodzieży w świetle literatury przedmiotu}

Niekiedy zamiennie używa się terminów dorastanie, dojrzewanie, czy adolescencja na określenie okresu w życiu młodych ludzi, który lokuje się pomiędzy dzieciństwem a dorosłością i charakteryzuje znaczną intensywnością przemian właściwe we wszystkich obszarach życia. W literaturze przedmiotu pojęcia te, choć zbliżone, mają różne wyjaśniania definicyjne. Zdaniem H. Bee, określanie w postaci liczby lat granic okresu dorastania jest problematyczne. Rozpoczyna się ono i kończy bowiem w różnym wieku, w zależności od płci, obszaru rozwoju (w innym czasie rozpoczynają się zmiany fizyczne, w innym emocjonalne i w obszarze rozwoju społecznego) czy szerokości geograficznej. Zdaniem autorki, zasadne jest przyjęcie założenia, że okres dorastania to ten okres w życiu człowieka, który znajduje się pomiędzy dzieciństwem a dorosłością, będący etapem przejściowym, podczas którego dziecko zmienia się pod względem fizycznym, umysłowym i emocjonalnym w człowieka

${ }^{1}$ E. Syrek, Zdrowie psychospołeczne młodzieży czasu wspótczesnych przemian - konteksty kształtowania umiejętności życiowych, [w:] Młodzież w dobie przemian społeczno-kulturowych, red. K. Segiet, Poznań 2015, s. 160. Choć oczywiście przyczyn tego stanu rzeczy może być niezwykle dużo.

2 Podaję za: tamże, s. 164. 
dorosłego. Orientacyjnie przyjmuje się, że w społeczeństwach uprzemysłowionych jest to okres od około 12. do około 20. roku życia ${ }^{3}$.

Na potrzeby analizy tytułowej kwestii, w artykule mowa będzie o seksualności osób w okresie dojrzewania, a szczególnie w drugiej fazie tegoż okresu, przypadającej od około 14. do około 18. roku życia. Jest to okres szczególnie intensywnych, i o doniosłym znaczeniu, zmian związanych z seksualnością człowieka ${ }^{4}$. Należy równocześnie zaznaczyć, że okres dorastania jest niezwykle zróżnicowany interindywidualnie ${ }^{5}$. Może okazać się to stresujące dla nastolatków. Jeśli widoczne zmiany związane z dojrzewaniem pojawiają się zbyt wcześnie lub zbyt późno względem rówieśników, może to nieść ze sobą określone konsekwencje ${ }^{6}$.

Dynamika rozwoju płciowego kobiet i mężczyzn jest różna, jednak oboje przechodzą w tej samej kolejności przez analogiczne procesy na drodze osiągania dojrzałości płciowej. Zmianie ulegają pierwszorzędowe cechy płciowe dotyczące jąder i penisa u chłopców oraz pochwy, macicy i jajników u dziewczynek oraz drugorzędowe cechy płciowe, na przykład powiększeniu ulegają piersi u kobiet, pojawia się zarost na twarzy oraz mutacja u mężczyzn, czy też owłosienie łonowe u kobiet i mężczyzn7.

Pomiędzy 11. a 15. rokiem życia u dziewcząt pojawia się pierwsza miesiączka. Choć jej występowanie jest konieczne dla płodności kobiety, nie oznacza jeszcze osiągnięcia pełnej dojrzałości płciowej w tym wymiarze ${ }^{8}$. Przez 2-4. lat od wystąpienia pierwszej miesiączki trwa faza niepłodności wieku

${ }^{3}$ H. Bee, Psychologia rozwoju człowieka, przekł. A. Wojciechowski, Poznań 2004, s. 326327. Por. np. M. Beisert, Trud dorastania seksualnego, [w:] Seksualność w cyklu życia człowieka, red. M. Beisert, Warszawa 2011, s. 146; W. Okoń, Wiek młodzieńczy, [w:] Nowy stownik pedagogiczny, red. W. Okoń, Warszawa 2007, s. 456; R. Łapińska, M. Żebrowska, Wiek dorastania, [w:] Psychologia rozwojowa dzieci i młodzieży, red. M. Żebrowska, Warszawa 1966, s. 382-383.

${ }^{4}$ Nazwy pokwitanie, dojrzewanie, pubertacja określające ten okres życia wzięły swój początek właśnie z łączenia go przez badaczy ze zmianami w obszarze seksualności. Ten fakt podkreśla, jak istotne miejsce zajmują zmiany związane z ludzką seksualnością w życiu nastolatków, skoro od nich nazwę wziął jeden z kilku zaledwie okresów w życiu człowieka. R. Łapińska, M. Żebrowska, Wiek dorastania, s. 382-383.

${ }^{5}$ J. Strelau (red.), Psychologia. Podręcznik akademicki, tom 1, Gdańsk 2003, s. 309.

${ }^{6}$ Jak dowodzi H. Bee, dziewczęta, które rozwijają się szybciej, doświadczają wielu negatywnych konsekwencji tego stanu rzeczy. W przypadku chłopców, szczególnie kłopotliwy jest opóźniony proces rozwoju płciowego. H. Bee, Psychologia rozwoju człowieka, s. 334-335. Z badań I. Obuchowskiej i A. Jaczewskiego wynika z kolei, że wcześnie dojrzewające dziewczęta doświadczają większej liczby problemów osobistych, konfliktów z rodzicami, zaś mężczyźni dojrzewający później są mniej popularni wśród rówieśników, oceniani jako mniej atrakcyjni i nadmiernie niespokojni, przy czym $\mathrm{w}$ badaniach podłużnych okazało się, że mężczyźni ci mieli niższy poziom samokontroli i byli bardziej zależni od innych ludzi niż ich rówieśnicy dojrzewający wcześniej. I. Obuchowska, A. Jaczewski, Rozwój erotyczny, Warszawa 2002, s. 53.

7 H. Bee, Psychologia rozwoju człowieka, s. 332.

${ }^{8}$ Tamże, s. 332. Badacze wyraźnie zauważyli zjawisko obniżania się wieku rozpoczęcia dojrzewania płciowego, czego wyrazem jest pojawianie się menarche u dziewcząt w coraz 
dojrzewania. Po jej zakończeniu kobieta staje się zdolna do zajścia w ciążę . Dziewczęta, z racji budowy anatomicznej, nie są świadome rozwoju swoich narządów płciowych, ale za to świadome zmian w zewnętrznej budowie ciała. Przeciętny wiek osiągnięcia przez kobiety zdolności do odczuwania orgazmu to $18-25$ rok życia ${ }^{10}$.

U chłopców ten wiek jest niższy, bardzo indywidualny; z sygnalnych badań można przyjąć, że pierwszych polucji chłopcy doświadczają średnio około 14. roku życia, a blisko pół roku wcześniej pierwszych orgazmów. Pojawia się u nich $\mathrm{w}$ wieku dojrzewania powiększenie zewnętrznych narządów płciowych oraz znaczna pobudliwość czuciowa w ich obrębie. Chłopcy często doświadczają wzwodów członka, będących nie tyle wynikiem pobudzenia erotycznego, ile niezależnego od nich i niekontrolowalnego przekrwienia narządów miednicy małej, przy jednoczesnym braku hamowania korowego ${ }^{11}$. Może powodować to wiele kłopotliwych i wstydliwych dla młodych mężczyzn sytuacji.

Zarówno kobiety, jak i mężczyźni doświadczają w okresie dojrzewania wzmożonego popędu seksualnego. Związane jest to z intensywnością wydzielania w tym czasie androgenów. Sposób realizacji tego popędu uwarunkowany jest wieloma czynnikami. Badacze zwracają uwagę między innymi na fakt, że istnieją przesłanki uzasadniające hipotezę, że popęd seksualny u kobiet „silniej podlega modyfikującemu działaniu czynników psychicznych niż popęd u chłopców"12. Niemniej, w wieku dorastania młodzież doświadcza wzmożonego popędu seksualnego i wypracowuje indywidualne sposoby radzenia sobie $\mathrm{z}$ tym faktem.

Podsumowując wątek zmian związanych z seksualnością nastolatków w wymiarze biologicznym, zauważa się, że dojrzewanie płciowe kobiet rozpoczyna się wcześniej i przebiega stosunkowo wolno, podczas gdy dojrzewanie płciowe mężczyzn zaczyna się później i ma przebieg bardziej dynamiczny. Niemniej, jak wynika z badań M. Beisert, najczęściej zarówno kobiety, jak i mężczyźni na pojawienie się fizycznych objawów dojrzewania reagują emocjami negatywnymi: lękiem, złością, rozpaczą ${ }^{13}$.

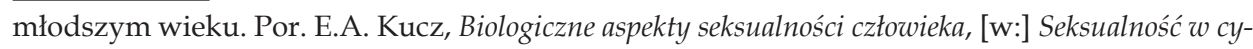
klu życia człowieka, red. M. Beisert, Warszawa 2011, s. 40-43.

9 I. Obuchowska, A. Jaczewski, Rozwój erotyczny, s. 44. Mogą jednak istnieć wyjątkowe sytuacje, kiedy w okresie niepłodności młoda kobieta jednak pozostaje płodna, choć statystycznie zdarza się to niezwykle rzadko.

10 Tamże, s. 44-45.

11 Tamże, s. 51, 48.

12 Tamże, s. 46-47. Por. Z. Izdebski, Seksualność Polaków na początku XXI wieku. Studium badawcze, Kraków 2012, s. 175.

${ }^{13}$ M. Beisert, Seks twojego dziecka, Poznań 1991, s. 112. 
Istotnym elementem rozwoju seksualnego adolescentów jest kształtowanie się tożsamości płciowej. Jest to niezwykle złożony proces, trwający od początku życia człowieka, a mający swój szczególnie istotny etap w okresie dojrzewania. Do dziś nie ma pewnej wiedzy, jakie czynniki dominują $\mathrm{w}$ procesie identyfikacji płciowej i przybierania roli płciowej. Z pewnością wiadomo, że dla identyfikacji płciowej istotne jest znaczenie uwarunkowań endogennych, środowiskowych i społecznych oraz że raz wykształcone poczucie przynależności do określonej płci ma nieodwracalny charakter ${ }^{14}$. W okresie adolescencji krystalizują się również sposoby realizacji ról płciowych. Są one związane ze społecznymi oczekiwaniami względem kobiet i mężczyzn, a dotyczą tego, jakie powinni realizować zadania, jak się zachowywać, jakie przejawiać postawy ${ }^{15}$.

Wraz z rozwojem płciowym młodzież zaczyna podejmować różnorodne formy aktywności seksualnej. W związku z odmiennością przebiegu tegoż rozwoju u kobiet i mężczyzn, zauważa się również różnice w ich aktywności seksualnej. Typowa dla pierwszego etapu okresu dorastania jest dezintegracja płciowa. Oznacza ona, że odczuwane podniecenie seksualne i gotowość do jego zaspokojenia nie są jeszcze zharmonizowane z uczuciowością i gotowością do stworzenia bliskiej, intymnej relacji z drugą osobą. U młodych mężczyzn droga do osiągnięcia integracji w tym wymiarze obejmuje dwa etapy. Pierwszy, trwający do około 14 . roku życia, związany jest z uniezależnianiem się od rodziców i budowaniem relacji z rówieśnikami. Jest to zwykle czas nasilonych konfliktów międzypokoleniowych. W drugim etapie wzrasta świadomość mężczyzn dotycząca zachodzących w nich zmian i zdolność kontrolowania swoich zachowań. Niemniej, wciąż odczuwane jest silne napięcie seksualne i potrzeba jego rozładowania. Mężczyźni w tym okresie dążą do nawiązywania bliższych relacji z kobietami, jednak wciąż dominuje dezintegracja seksualna, w wyniku doświadczania której chłopcy poruszają się w sytuacji skrajności. Z jednej strony odczuwają winę z powodu ekspresji seksualnej, z drugiej zaś - przyjemność z niej płynącą. Ponadto, mężczyźni w tym okresie z powodu niepełnej dojrzałości emocjonalnej zwykle na zewnątrz demonstrują zachowania seksualne pozbawione miłości i emocji, z drugiej zaś skrywają w sobie pragnienie bliskości z drugą osobą. Zintegrowanie seksualności następuje dopiero w końcu okresu dojrzewania.

Droga ku integracji seksualnej okresu dorastania prowadzi u chłopców od nadmiernego akcentowania elementu pobudzenia seksualnego do połączenia go z uczuciami; od poszukiwania partnerek, które spełnią tylko jeden rodzaj oczekiwań, do wiązania

${ }^{14}$ K. Nowosielski, Identyfikacja i rola ptciowa, [w:] Podstawy seksuologii, red. Z. Lew-Starowicz, V. Skrzypulec, Warszawa 2010, s. 99.

${ }^{15}$ L. Brannon, Psychologia rodzaju, Gdańsk 2002, s. 210. 
się z osobami, które potrafią zaspokoić całą paletę potrzeb; od niewielkich wymagań stawianych obiektom zainteresowań seksualnych do starannych poszukiwań kobiety o cechach niepowtarzalnych ${ }^{16}$.

Dorastające dziewczynki, podobnie jak chłopcy, dążą do uniezależnienia się od rodziców i nawiązania bliższych relacji z rówieśnikami, co skutkuje wzmożoną liczbą konfliktów wewnątrzrodzinnych. Dorastająca dziewczyna, inaczej niż w przypadku chłopców, odczuwa niewielkie podniecenie seksualne; seksualność wyraża się $\mathrm{w}$ tym okresie w pragnieniu nawiązania więzi uczuciowej i doświadczania bliskości. Zawierane związki zwykle są krótkotrwałe, między innymi ze względu na rozbieżność potrzeb i oczekiwań młodych kobiet i mężczyzn. Dezintegracja seksualności dziewcząt wyraża się $\mathrm{w}$ pierwszej kolejności $\mathrm{w}$ demonstracyjnym zaprzeczaniu i eliminowaniu seksualności z codziennego funkcjonowania ${ }^{17}$. Niekiedy może przybrać formę wzmożonego zainteresowania innymi kobietami, szczególnie takimi, które mogłyby stać się swoistym wzorem dla dorastającej dziewczyny. Około 16. roku życia następuje druga faza dojrzewania dziewcząt, w której do głosu dochodzi pobudzenie seksualne, wymagające reakcji młodej kobiety na nie. Jest to również czas tworzenia związków z mężczyznami, w których pojawia się coraz więcej zachowań seksualnych.

Zamiast zaprzeczania seksualności, pojawia się świadomość stanów podniecenia i ich akceptacja. Zamiast idealizowania zachowań aseksualnych, następuje stopniowa akceptacja złożonej natury potrzeby seksualnej. Integracja tych dwóch aspektów seksualności będzie przejawiać się jako zwiększająca się świadomość własnych pragnień seksualnych, jako ich akceptacja oraz jako zdolność do podejmowania dojrzałej decyzji, z kim i kiedy nastąpi ich realizacja. Integracja dokonująca się u progu dorosłości polega na traktowaniu bliskości fizycznej i emocjonalnej jako całości zbudowanej z różnych jakościowo i równoważnych elementów ${ }^{18}$.

Ekspresja seksualna w wieku dorastania przechodzi od form niedojrzałych do dojrzałych. Od 60 - 90\% chłopców w wieku dorastania i od 1 - 40\% dziewcząt posiada doświadczenie masturbacji. Masturbacja młodzieńcza jest zjawiskiem mieszczącym się $\mathrm{w}$ normie rozwojowej i ma charakter przejściowy $^{19}$. Niemniej, ta forma aktywności seksualnej młodzieży często bywa oceniana przez osoby dorosłe negatywnie ${ }^{20}$, również niezgodna jest $\mathrm{z}$ normami

${ }^{16}$ M. Beisert, Trud dorastania seksualnego, s. 146-149.

${ }^{17}$ W skrajnym wariancie tej postawy mówi się o ascezie okresu dojrzewania. Tamże, s. $150-151$.

18 Tamże.

19 Tamże, s. 159-162. Por. Z. Izdebski, Seksualność Polaków na początku XXI wieku, s. 184-185.

${ }^{20}$ Z badań Z. Izdebskiego wynika, że 25\% dorosłych respondentów żywi przekonanie, że masturbacja może prowadzić do zaburzeń psychicznych/zdrowotnych. Z. Izdebski, Seksualność Polaków w dobie HIV/AIDS. Studium porównawcze 1997-2001-2005, Zielona Góra 2006, s. 46. 
moralnymi Kościoła katolickiego ${ }^{21}$, co może potęgować negatywne odczucia praktykujących ją adolescentów.

Niekiedy przyjmuje się, że pośrednią formą aktywności seksualnej, pomiędzy autostymulacją a stosunkiem seksualnym, jest petting. W literaturze wyróżnia się dwie formy tego rodzaju aktywności: petting oznaczający pieszczoty genitalne i necking oznaczający stymulowanie górnych części ciała, głównie piersi, w celu osiągnięcia orgazmu. Młode kobiety i mężczyźni przejawiają nieco inny stosunek do pettingu. Kobiety częściej traktują go jako oddzielną i równoprawną formę kontaktów seksualnych, obok stosunku płciowego, dla mężczyzn zaś częściej jest on formą wstępu do stosunku seksualnego ${ }^{22}$. Co istotne, rodzice nastolatków przejawiają większą akceptację dla tej formy kontaktów seksualnych swoich dzieci niż stosunków płciowych, zapewne ze względu na niskie ryzyko zajścia w ciążę i zakażenia chorobami przenoszonymi drogą płciową ${ }^{23}$.

Bardzo istotnym wydarzeniem w życiu każdego człowieka jest inicjacja seksualna. Współcześnie odnotowuje się obniżenie wieku jej doświadczania. $W$ reprezentatywnych badaniach $Z$. Izdebskiego, średni wiek inicjacji kobiet wynosił 16,4, dla mężczyzn 15,1. Graniczny wiek inicjacji, to znaczy taki, po którym odsetek osób inicjujących życie seksualne istotnie spada, w przypadku i kobiet i mężczyzn wynosi 17 lat. Istotne różnice natomiast odnotowuje się w powodach rozpoczęcia życia seksualnego. Dla zdecydowanej większości kobiet kluczowym motywem do podjęcia współżycia jest miłość, podczas gdy mężczyźni wśród trzech najważniejszych powodów, dla których rozpoczęli aktywność seksualną, wymieniają podniecenie seksualne, przyjemność i ciekawość ${ }^{24}$. Kobiety i mężczyźni w odmienny sposób w okresie dojrzewania przeżywają swoją seksualność, co może prowadzić do wzajemnego niezrozumienia i rozczarowania.

Istotny jest również kontekst kulturowy rozwoju seksualnego młodzieży. Zauważa się w nim wiele zjawisk i procesów, które podlegają badaniom odnośnie ich znaczenia dla funkcjonowania młodzieży. Wymienić w tym kontekście można między innymi: zniesienie lub przynajmniej zmniejszenie przestrzeni tabu wokół seksualności ${ }^{25}$, seksualizację $e^{26}$, zmiany społeczne rzu-

${ }^{21} \mathrm{~W}$ badaniach Z. Izdebskiego 42\% respondentek zadeklarowała, że zaniechała praktyki masturbowania się z powodu poczucia grzechu. Z. Izdebski, Seksualność Polaków na początku XXI wieku, s. 185.

${ }_{22}$ M. Beisert, Trud dorastania seksualnego, s. 162-163.

23 Tamże, s. 163.

24 Z. Izdebski, Seksualność Polaków na początku XXI wieku, s. 176-177.

25 Zob. B. Smoter, Tabu seksualne w rodzinie i szkole. W poszukiwaniu (nie)obecnych kategorii, Chowanna, 2013, 2, s. 145-155.

${ }^{26}$ Zob. K. Waszyńska, M. Zielona-Jenek, Zjawisko seksualizacji jako wyzwanie dla współczesnej edukacji', Studia Edukacyjne, 2016, 39, s. 351-375. 
tujące na zmiany relacji międzyludzkich ${ }^{27}, \mathrm{w}$ tym demokratyzację ${ }^{28}$, czy też zmiany związane stricte z pozycją kobiet i mężczyzn ${ }^{29}$. Nadto, wiele zachowań seksualnych młodzieży jest obiektem ocen różnych środowisk i osób. Można mniemać, że aksjonormatywny spór toczący się wokół seksualności młodzieży może być dla niej samej kłopotliwy.

Młodzież doświadcza zmian związanych z seksualnością właściwie w każdym obszarze życia. Zmienia się ciało, zmienia się charakter relacji z rodzicami i rówieśnikami, zmieniają się podejmowane aktywności, adolescenci stoją w obliczu nowych wyzwań, odpowiedzialności i decyzji. W wyniku pojawienia się tak wielu i tak znaczących zmian, adolescenci mogą odczuwać związany z nimi stres.

\section{Stres w świetle literatury przedmiotu}

Literatura przedmiotu wskazuje na dwie tradycje, w ramach których wypracowano dwa modele mechanizmu powstawania stresu. Pierwszy, fizjologiczny, przypisywany jest H. Selyemu, autorstwo zaś drugiego, psychologicznego modelu należy do R. Lazarusa ${ }^{30}$.

W modelu fizjologicznym stres jest rozumiany jako konsekwencja zaburzenia mechanizmów równowagi organizmu pod wpływem stresorów. Według H. Selyeego, w optyce nauk medycznych stres jest niespecyficzną reakcją organizmu nazywaną Ogólnym Zespołem Adaptacyjnym (General Adaptation Syndrom - GAS). Powstaje ona w odpowiedzi na działanie stresorów rozumianych jako szkodliwe dla organizmu bodźce. GAS można podzielić na trzy kolejne etapy: stadium reakcji alarmowej, w której następuje mobilizacja sił obronnych, stadium odporności, to jest pełnego przystosowania do stresora i stadium wyczerpania, kiedy nie następuje adaptacja organizmu do doświadczanych zmian ${ }^{31}$. Psychologiczne badania prowadzone $\mathrm{w}$ tym modelu koncentrują się na analizie różnic indywidualnych w reakcjach na stresory ${ }^{32}$.

H. Selye zapoczątkował rozwój badań naukowych nad stresem. Jego koncepcja spotkała się jednak z krytyką. Wiązała się ona z pozyskanymi do-

\footnotetext{
27 Zob. A. Giddens, Przemiany intymności. Seksualność, miłość i erotyzm we wspótczesnych społeczeństwach, przekł. A. Szulżycka, Warszawa 2006.

${ }^{28}$ Zob. J. Ostruch-Kamińska, Demokratyzacja relacji matżeńskich i rodzicielskich we wspótczesnych rodzinach, Roczniki Pedagogiczne, 2017, 4, s. 5-17.

${ }_{29}$ Zob. L. Marszałek, Kulturowe uwarunkowania roli kobiety we wspótczesnym społeczeństwie, Seminare. Poszukiwania naukowe, 2008, 25, s. 267-279.

${ }^{30}$ A. Bańka, Społeczna psychologia środowiskowa, Warszawa 2002, s. 184-185.

${ }^{31}$ I. Heszen-Niejodek, Teoria stresu psychologicznego i radzenia sobie, [w:] Psychologia. Podręcznik akademicki, tom 3, red. J. Streulau, Gdańsk 2005, s. 465-466.

${ }^{32}$ A. Bańka, Społeczna psychologia środowiskowa, Warszawa 2002, s. 185.
} 
wodami, że reakcje organizmu na stresory bywają specyficzne oraz z niedostatecznym uwzględnianiem w koncepcji fizjologicznej czynników psychologicznych $^{33}$. W wyniku naukowych poszukiwań uwzględniających tę właśnie perspektywę, ukształtowany został inny model mechanizmu powstawania stresu - psychologiczny. Nie kwestionuje on założeń modelu fizjologicznego, a „przyjmuje go jako część ogólniejszego mechanizmu tworzenia się reakcji stresowych" 34 .

Dla R. Lazarusa, który położył fundament pod koncepcję stresu psychologicznego, kluczowe znaczenie ma kontekst sytuacyjny oraz relacja pomiędzy osobą a jej otoczeniem i to nie tylko w kontekście sytuacji stresowych, ale wszystkich form aktywności człowieka. Zdaniem R. Lazarusa, człowiek nieustannie dokonuje oceny relacji z otoczeniem, szczególnie tych elementów, które są ważne dla dobrostanu osoby. W ujęciu tym, relacja może zostać oceniona na trzy sposoby: jako niemająca znaczenia, sprzyjająco-pozytywna lub stresująca. R. Lazarus i S. Folkman przyjęli fenomenologiczno-poznawczą koncepcję stresu, gdzie stresem jest „określona relacja (relationship) między osobą a otoczeniem, która oceniana jest przez osobę jako obciążająca lub przekraczająca jej zasoby i zagrażająca jej dobrostanowi" ${ }^{35}$. Relacja, o której piszą Lazarus i Folkman ma charakter transakcji. Na całość zjawiska stresu składają się i osoba, i sytuacja, którą ona odbiera jako stresującą, przy czym ich właściwości nie są jedynie sumą elementów składowych ${ }^{36}$.

W koncepcji tej akcent najpierw położony jest na subiektywną ocenę znaczenia relacji przez poszczególne osoby. Nie właściwości obiektywne, a subiektywne odczucia sprawiają, że określona relacja w danym przypadku jest stresująca lub nie ${ }^{37}$. Osoba dokonuje tak oceny pierwotnej. Jednocześnie dokonuje ona oceny wtórnej, polegającej na oszacowaniu własnych możliwości poradzenia sobie z sytuacją stresującą. Warunkiem koniecznym pojawienia się obu ocen jest uznanie przez osobę (świadomie lub nie), że doświadczana sytuacja ma istotne znaczenie ${ }^{38}$.

Interesującą, z perspektywy doświadczania stresu związanego ze sferą seksualności, koncepcję stresu przedstawia S. Hobfoll. W jej myśl, jest on związany z zasobami osobowymi, a dokładnie rzecz ujmując - z zagrożeniem ich utraty, wyeksploatowania lub niemożności pomnażania. Autor omawianej Conservation of Resources Theory wymienia cztery rodzaje zasobów, którymi dysponuje osoba: przedmioty, okoliczności, właściwości osobiste oraz

\footnotetext{
33 I. Heszen-Niejodek, Teoria stresu psychologicznego, s. 466.

34 A. Bańka, Społeczna psychologia środowiskowa, s. 186.

35 Podaję za: I. Heszen-Niejodek, Teoria stresu psychologicznego, s. 470.

36 A. Grygorczuk, Pojęcie stresu w medycynie i psychologii, Psychiatria, 2008, 5, 3, s. 113.

37 I. Heszen-Niejodek, Teoria stresu psychologicznego, s. 470.

38 A. Grygorczuk, Pojęcie stresu w medycynie i psychologii, Psychiatria, 2008, 5, 3, s. 113.
} 
warunki i czynniki sprzyjające. Stres powstaje wówczas, kiedy następuje rzeczywista lub subiektywnie stwierdzona utrata zasobów.

Stresorami natomiast określa się czynniki wywołujące stres. Mogą być one rozpatrywane z różnych punktów widzenia, z uwzględnieniem różnych ich właściwości. W perspektywie natężenia stresorów wymienia się dramatyczne wydarzenia o skali katastrof obejmujących bardzo wiele osób, poważne wyzwania i zagrożenia dotyczące pojedynczych osób lub grup oraz drobne, codzienne trudności ${ }^{39}$.

Uwzględniając wymiar czasowy stresorów, wyróżnia się wydarzenia stresowe jednorazowe (np. nieprzyjemne spotkanie), cykliczne lub periodyczne, powtarzające się z określoną częstotliwością (np. spotkania opłatkowe), stresory chroniczne, działające w sposób ciągły (np. nieudany związek małżeński) oraz sekwencje stresorów, to jest ciąg wydarzeń stresowych, w których wystąpienie jednego stresora pociąga za sobą wystąpienie kolejnego (np. rozwód rodziców, pociągający za sobą konieczność zmiany miejsca zamieszkania, co z kolei skutkuje koniecznością zmiany szkoły i np. częstotliwości kontaktów z przyjaciółmii) ${ }^{40}$.

Istotną cechą stresorów jest ich kontrolowalność, „czyli to, w jakim stopniu ich występowanie, przebieg i następstwa zależą od celowego działania osób zaangażowanych" ${ }^{41}$. Zdarzenia stresowe mogą mieć charakter niekontrolowany, kontrolowany lub częściowo kontrolowany - w pewnych okolicznościach lub zakresie. Ze względu na możliwości kontrolowania sytuacji stresowych, osoba podejmuje określoną aktywność, określaną mianem radzenia sobie ze stresem ${ }^{42}$.

Istnieje wiele różnych strategii radzenia sobie ze stresem. Według wspomnianych R. Lazarusa i S. Folknam, w obliczu stresu osoba może dążyć do zmiany sytuacji wywołującej ten stan (mowa tu o strategii zorientowanej zadaniowo, w jej obszarze autorzy wymieniają dwie szczegółowe formy) i/lub dążyć do zmiany swojego wewnętrznego stanu stresu (tutaj mowa o strategii zorientowanej emocjonalnie, $w$ jej obszarze autorzy wymieniają sześć szczegółowych form $)^{43}$. W perspektywie czasowej, R. Schwarzer i S. Taubert skonstruowali koncepcję proaktywnego radzenia sobie. Na podstawie osiągnięć, jakie dokonali T.A. Beehr i J.E. McGrath, wskazano pięć typów zachowań zaradczych związanych ze stresem w perspektywie czasowej. Należą do nich: radzenie sobie prewencyjne, antycypacyjne, dynamiczne, reaktywne i rezy-

${ }^{39}$ I. Heszen-Niejodek, Teoria stresu psychologicznego, s. 474.

${ }^{40}$ Tamże.

${ }^{41}$ Tamże.

${ }^{42}$ Tamże, s. 475. Choć zagadnienie radzenia sobie ze stresem jest ważnym elementem powoływanej w artykule koncepcji stresu Lazarusa i Folkman, to jednak nie zostanie w tym miejscu szerzej omówiony.

43 Podaję za: J. Czapiński, Psychologia szczęścia, Warszawa 2017, s. 312-313. 
dualne ${ }^{44}$. Młodzież w kontekście swojej seksualności doświadcza różnorodnych stresów, gdzie niektóre są związane z aktualnymi doświadczeniami, inne dotyczą bliższej lub dalszej przyszłości. Szczegółowa analiza powyższych strategii radzenia sobie z doświadczanym stresem nie jest konieczna $\mathrm{w}$ perspektywie podjętego problemu badawczego.

\section{Metodologia badań}

Przedmiot badań stanowią stresory oraz natężenie stresu odczuwanego przez młodzież w różnych przestrzeniach życiowych w kontekście ich seksualności. Celem przeprowadzonych badań jest identyfikacja stresorów i pomiar natężenia stresu odczuwanego w różnorodnych przestrzeniach życiowych nastolatków w kontekście ich seksualności. Założony cel nadał badaniu charakter diagnostyczny. Główny problem badawczy przyjął postać pytania: Jakie są stresory oraz natężenie stresu odczuwanego przez młodzież w różnorodnych przestrzeniach życiowych w kontekście ich seksualności? Przyjęto następujące szczegółowe problemy badawcze: Jakich stresorów oraz jakiego natężenia stresu doświadcza młodzież w przestrzeni osobistej? Jakich stresorów oraz jakiego natężenia stresu doświadcza młodzież w przestrzeni rodzinnej? Jakich stresorów oraz jakiego natężenia stresu doświadcza młodzież w przestrzeni aktywności seksualnej? Jakich stresorów oraz jakiego natężenia stresu doświadcza młodzież w przestrzeni relacji z rówieśnikami? Jakich stresorów oraz jakiego natężenia stresu doświadcza młodzież w przestrzeni kulturowej?

Na potrzeby niniejszego artykułu zostały przeprowadzone badania empiryczne metodą sondażu diagnostycznego. Wykorzystano technikę ankietowania, zaś narzędzie badawcze stanowił autorski kwestionariusz ankiety. W badaniu wzięło udział 100 osób w wieku 17-18 lat, uczących się w szkołach ponadgimnazjalnych z obszaru gminy i miasta Szczecin. Wśród ankietowanych było 71 kobiet i 29 mężczyzn. Badanie przeprowadzono we wrześniu 2018 roku.

Analiza statystyczna uzyskanych wyników została przeprowadzona w pakiecie IBM SPSS Statistics v.25. Wykorzystano techniki opisu statystycznego z testem Shapiro-Wilka w celu oceny, czy uzyskane w badaniu rozkłady cech ilościowych są istotnie różne, czy podobne do rozkładu normalnego, typowego dla ogólnej populacji. Nieistotny wynik tego testu świadczy o zgodności rozkładu empirycznego z normalnym, czyli takim, w którym przeważają wyniki przeciętne, a im wynik niższy lub wyższy, tym rzadziej

${ }^{44}$ Podaję za: A. Falewicz, Psychologiczne koncepcje stresu i radzenia sobie, Studia Paradyskie, 2017, 27, s. 285-286. 
występujący. Rozkład normalny przyjmuje charakterystyczny kształt dzwonka (krzywa Gaussa).

Do weryfikacji hipotez badawczych wykorzystano metodę tabel krzyżowych ze współczynnikiem chi-kwadrat Pearsona dla danych nominalnych, porównywanie dwóch grup testem U Manna-Whitneya dla zmiennych ciągłych oraz metodę korelacji parami ze współczynnikiem rho Spearmana. Pojedyncze braki w odpowiedziach uzupełniono o wartości niediagnostyczne (środkowe dla zmiennych ciągłych i zerowe dla dychotomicznych). Za wskaźnik istotności statystycznej przyjęto wartość $\mathrm{p}<0,05$, zaś wartość $\mathrm{p}<0,1$ przyjęto za wskaźnik nie w pełni istotnej tendencji statystycznej.

\section{Wyniki badań}

Największe nasilenie stresu młodzież odczuwała w przestrzeni aktywności seksualnej (średnia 4,0745). Nieco niższe nasilenie stresu badani deklarowali w przestrzeni kulturowej i relacji z rówieśnikami (odpowiednio średnia 3,26 i 3,22). Najniższe natężenie stresu badani odczuwali w przestrzeni rodzinnej (średnia 2,61) oraz osobistej (średnia 1,92). Dane te przedstawione zostały w tabeli 1.

Tabela 1

Natężenie stresu odczuwanego przez młodzież w poszczególnych przestrzeniach życiowych w kontekście seksualności

\begin{tabular}{|l|c|c|c|c|c|c|c|}
\hline \multicolumn{1}{|c|}{$\begin{array}{c}\text { Przestrzeń } \\
\text { życiowa } \\
\text { w kontekście } \\
\text { seksualności }\end{array}$} & Min. & Maks. & Średnia & $\begin{array}{c}\text { Odchyle- } \\
\text { nie stan- } \\
\text { dardowe }\end{array}$ & $\begin{array}{c}\text { Sko- } \\
\text { śność }\end{array}$ & Kurtoza & $\begin{array}{c}\text { Test } \\
\text { S-W }\end{array}$ \\
\hline Osobista & 0,00 & 6,92 & 1,92 & 1,48 & 0,936 & 0,488 & $<0,001$ \\
\hline Rodzinna & 0,00 & 9,80 & 2,61 & 1,86 & 1,378 & 2,219 & $<0,001$ \\
\hline $\begin{array}{l}\text { Aktywności } \\
\text { seksualnej }\end{array}$ & 0,00 & 10,00 & 4,07 & 2,26 & 0,295 & $-0,545$ & 0,103 \\
\hline $\begin{array}{l}\text { Relacji z rówie- } \\
\text { śnikami }\end{array}$ & 0,00 & 10,00 & 3,22 & 2,26 & 0,512 & $-0,389$ & 0,002 \\
\hline Kulturowa & 0,00 & 9,38 & 3,26 & 2,15 & 0,488 & $-0,285$ & 0,012 \\
\hline
\end{tabular}

Źródło: badania własne.

${ }^{45}$ Skala mieściła się każdorazowo w przedziale od 0 do 10. 


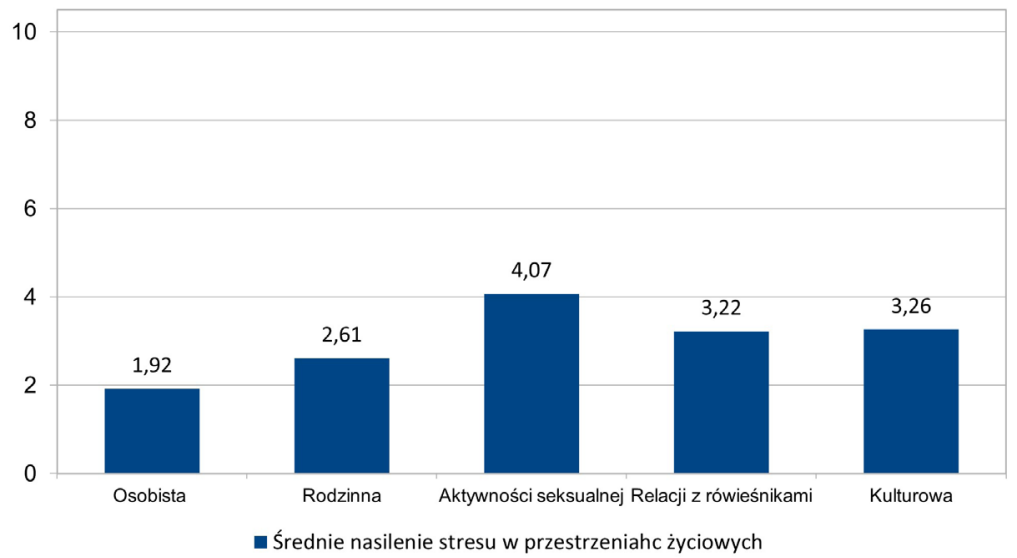

Ryc. 1. Średnie natężenie stresu odczuwanego przez młodzież w poszczególnych przestrzeniach życiowych w kontekście seksualności

(źródło: badania własne)

Tylko rozkład wyników w przestrzeni seksualnej był zbliżony do normalnego, o czym świadczy nieistotny statystycznie wynik testu Shapiro-Wilka. Oznacza to, że w grupie dominowały osoby o przeciętnym nasileniu stresu dotyczącego swojej seksualności, zaś wyniki niskie i wysokie występowały porównywalnie rzadziej, co zobrazowano na rycinie 2.

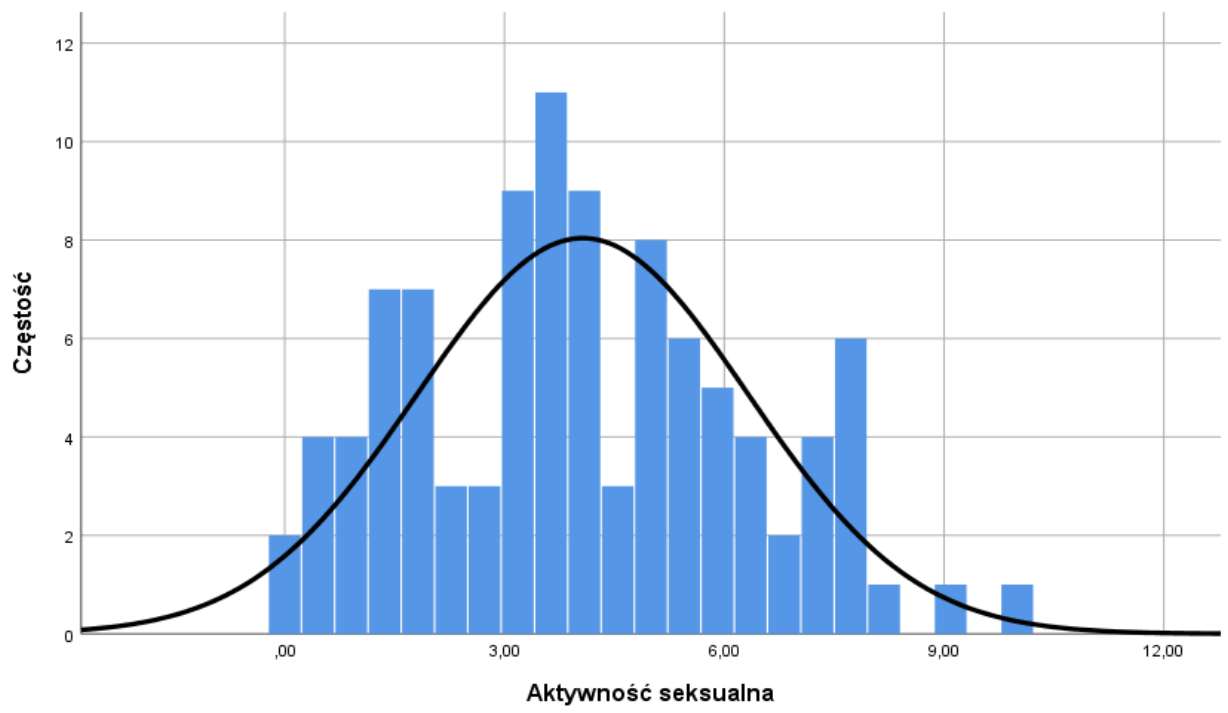

Ryc. 2. Histogram rozkładu średniego nasilenia stresu w przestrzeni aktywności seksualnej (źródło: badanie własne) 
Pozostałe rozkłady są istotnie odmienne od krzywej Gaussa. Podwyższona skośność rozkładu wyników w przestrzeniach osobistej i rodzinnej wskazuje, że przeważały oceny niskie. Obniżona kurtoza w rozkładach wyników dotyczącej przestrzeni relacji z rówieśnikami i kulturowej sygnalizuje brak typowej dla ogólnej populacji przewagi wyników średnich nad skrajnymi.

Badane kobiety cechowały się tendencją do odczuwania większego natężenia stresu w przestrzeni kulturowej niż mężczyźni. Dane te przedstawione zostały $\mathrm{w}$ tabeli 2 . Wynik ten jest uzasadniony w perspektywie kulturowych kanonów odnoszących się do kobiet i mężczyzn. Społeczne oczekiwania i zmiany związane z realizacją kobiecości w kulturze zachodniej w większej mierze dotyczą współcześnie kobiet niż mężczyzn (np. kanon piękna czy ideał businesswoman).

Tabela 2

Natężenie odczuwanego stresu wśród badanych kobiet i mężczyzn

\begin{tabular}{|l|c|c|c|c|c|c|}
\hline \multirow{2}{*}{$\begin{array}{c}\text { Przestrzenie } \\
\text { życiowe } \\
\text { w kontekście } \\
\text { seksualności }\end{array}$} & \multicolumn{2}{|c|}{$\begin{array}{c}\text { Kobiety, } \\
\mathrm{n}=71\end{array}$} & \multicolumn{2}{c|}{$\begin{array}{c}\text { Mężczyźni, } \\
\mathrm{n}=21\end{array}$} & \multicolumn{2}{c|}{$\begin{array}{c}\text { Test } \\
\text { U Manna-Whitneya }\end{array}$} \\
\cline { 2 - 7 } & $\mathrm{M}$ & $\mathrm{SD}$ & $\mathrm{M}$ & $\mathrm{SD}$ & $\mathrm{Z}$ & $\mathrm{P}$ \\
\hline Osobista & 1,83 & 1,37 & 2,15 & 1,73 & $-0,512$ & 0,605 \\
\hline Rodzinna & 2,39 & 1,66 & 3,15 & 2,21 & $-1,581$ & 0,114 \\
\hline $\begin{array}{l}\text { Aktywności sek- } \\
\text { sualnej }\end{array}$ & 4,14 & 2,24 & 3,88 & 2,33 & $-0,707$ & 0,480 \\
\hline $\begin{array}{l}\text { Relacji z rówie- } \\
\text { śnikami }\end{array}$ & 3,19 & 2,22 & 3,30 & 2,40 & $-0,053$ & 0,958 \\
\hline Kulturowa & 3,52 & 2,19 & 2,60 & 1,94 & $-1,869$ & 0,062 \\
\hline
\end{tabular}

Źródło: badania własne.

W badanej grupie wykryto dwie w pełni istotne zależności (o słabych siłach i ujemnych kierunkach) pomiędzy natężeniem stresu w poszczególnych przestrzeniach życiowych młodzieży w kontekście seksualności a ich religijnością. Wraz ze wzrostem religijności badanych wzrastało natężenie stresu $\mathrm{w}$ przestrzeni osobistej (rho $=0,220 ; \mathrm{p}=0,028$ ) oraz kulturowej (rho $=0,241$; $\mathrm{p}=0,016)$. Zauważono również nie $\mathrm{w}$ pełni istotną tendencję statystyczną do odczuwania większego natężenia stresu $\mathrm{w}$ przestrzeni relacji rówieśniczych wśród osób bardziej religijnych (rho $=0,183 ; \mathrm{p}=0,069)$. Dane te przedstawiono w tabeli 3. Poszukując uzasadnienia tych zależności, w przypadku stresu odczuwanego w przestrzeni kulturowej, można postawić hipotezę o przywiązaniu osób o silniejszej religijności do stałości, uniwersalnych wartości czy bardziej tradycyjnego obrazu funkcjonowania kobiet i mężczyzn w kulturze 


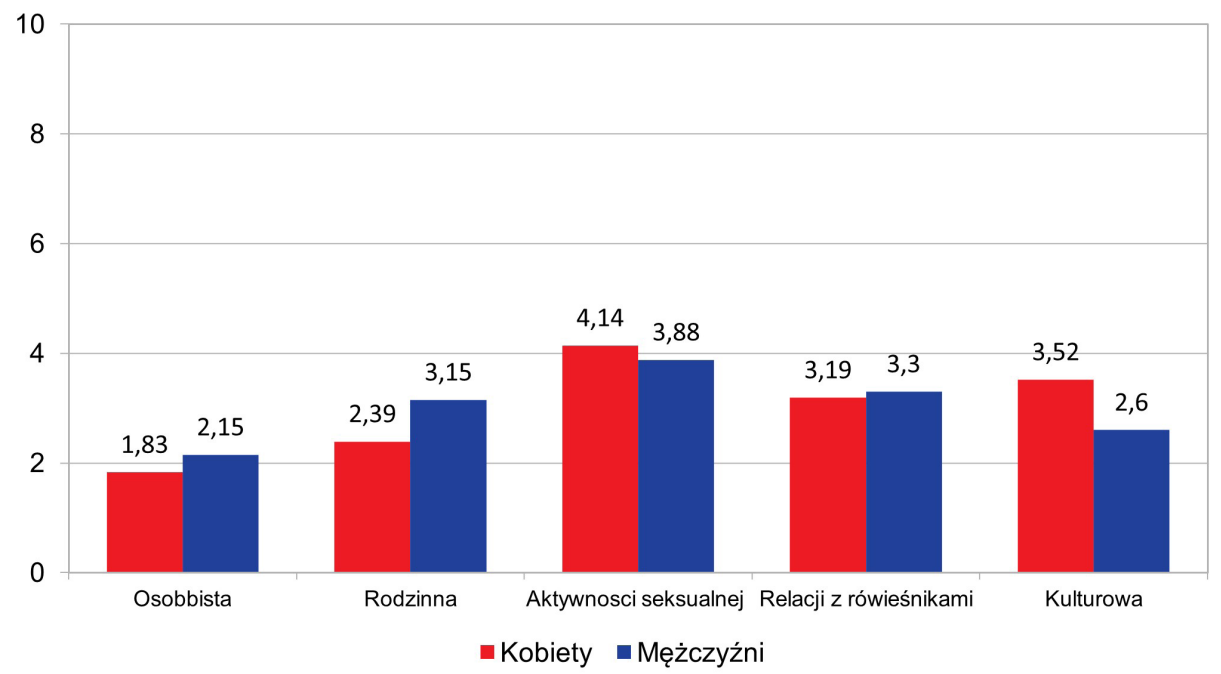

Ryc. 3. Średnie natężenie odczuwanego stresu wśród badanych kobiet i mężczyzn (źródło: badania własne)

- ekstrapolując stanowisko Kościoła katolickiego w tych kwestiach na przekonania jego wiernych. Weryfikacja tej hipotezy wymaga przeprowadzenia szczegółowych badań.

Tabela 3

Korelacja pomiędzy natężeniem stresu w poszczególnych przestrzeniach życiowych młodzieży w kontekście seksualności a nasileniem jej religijności

\begin{tabular}{|c|c|c|c|c|c|c|}
\hline & & \multicolumn{4}{|c|}{$\begin{array}{r}\text { Przestrzenie życiowe młodzieży } \\
\text { w kontekście seksualności }\end{array}$} \\
\cline { 4 - 7 } & $\begin{array}{c}\text { Współ- } \\
\text { czynniki } \\
\text { korelacji }\end{array}$ & \multicolumn{1}{|c|}{ osobista } & rodzinna & $\begin{array}{c}\text { aktywno- } \\
\text { ści seksu- } \\
\text { alnej }\end{array}$ & $\begin{array}{c}\text { relacji } \\
\text { z rówie- } \\
\text { śnikami }\end{array}$ & kulturowa \\
\cline { 5 - 8 } & Rho & 0,220 & 0,032 & 0,128 & 0,183 & 0,241 \\
\hline $\begin{array}{c}\text { Stosunek } \\
\text { do wiary } \\
\text { religijnej }\end{array}$ & $\mathrm{P}$ & 0,028 & 0,780 & 0,204 & 0,069 & 0,016 \\
\hline
\end{tabular}

Średnie nasilenie stresu $\mathrm{w}$ przestrzeni osobistej wyniosło $\mathrm{w}$ badanej grupie 1,92 i można je określić jako niskie. Porównując natężenia stresu we wszystkich pięciu przestrzeniach życiowych adolescentów w kontekście ich seksualności, w obszarze osobistym natężenie to było najniższe, i dla kobiet, i dla mężczyzn, choć ci drudzy przejawiali nieco wyższe średnie natężenie stresu $(2,15)$ niż kobiety $(1,83)$. 
Najsilniejszym stresorem dla badanej młodzieży w tym obszarze (średnia $2,94)$ było odczuwanie wyjątkowo silnych, często zmieniających się emocji. Stresorami o nieco mniejszym znaczeniu były odczuwane napięcie seksualne (średnie natężenie 2,44) oraz dokonujące się $\mathrm{w}$ badanych osobach zmiany fizyczne związane z dojrzewaniem, takie jak przyrost masy ciała czy miesiączkowanie/polucje. Stresorem, który miał najmniejsze znaczenie dla badanych w tym obszarze (średnia 0,51) było doświadczenie własnej kobiecości/męskości.

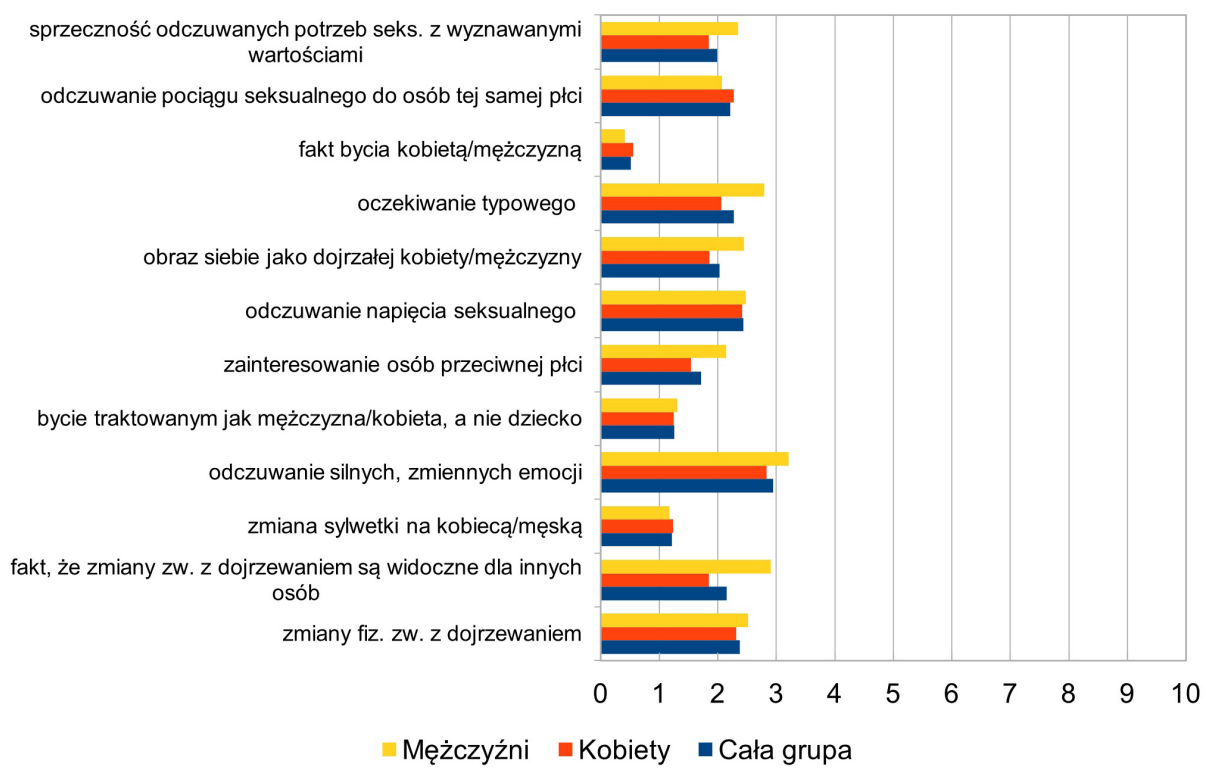

Ryc. 4. Średnie natężenie stresu badanej młodzieży w przestrzeni osobistej

Średnie natężenie stresu w przestrzeni rodzinnej wyniosło w badanej grupie 2,61 i można je określić jako niskie. Porównując wyniki uzyskane przez kobiety i mężczyzn w tym zakresie, kobiety cechowały się niższym natężeniem stresu $(2,39)$ niż mężczyźni $(3,15)$. Najsilniejszymi stresorami w tym obszarze dla badanych osób były sytuacja przedstawienia rodzicom swojej sympatii (średnia 3,99), rozmowy z rodzicami o uczuciach (średnia 3,87) oraz rozmowy z rodzicami o seksie i dojrzewaniu (średnia 3,62). Stresorem o najmniejszym znaczeniu w tym obszarze (średnia 1,38 ) były sytuacje okazywania przez rodziców uczuć swoim dzieciom. 


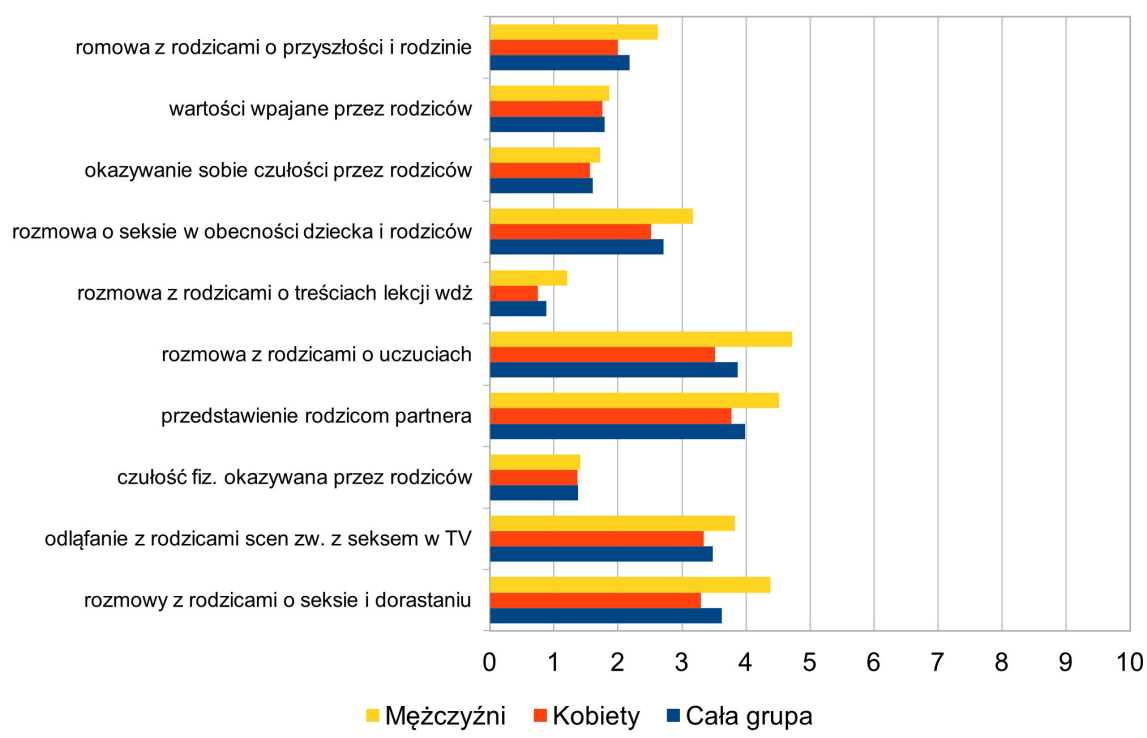

Ryc. 5. Średnie natężenie stresu badanej młodzieży w przestrzeni rodzinnej (źródło: badania własne)

Odnotowano, że w przypadku stresora, jakim są rozmowy z rodzicami na temat seksu i dojrzewania, mężczyźni wykazywali nie w pełni istotną tendencję do odczuwania silniejszego natężenia stresu niż kobiety $[Z=-1,826$; $\mathrm{p}=0,068]$. Podobnie miało to miejsce $\mathrm{w}$ przypadku stresora, jakim są rozmowy z rodzicami na temat wartości, rodziny i osobistych planów na przyszłość $[Z=-1,686 ; p=0,092]$.

Średnie natężenie stresu $\mathrm{w}$ obszarze aktywności seksualnej wynosiło wśród badanej młodzieży 4,07 i było najwyższe ze wszystkich obszarów. Mężczyźni przejawiali w tym obszarze niższe natężenie stresu (średnia 3,88) niż kobiety $(4,14)$. Ogólnie można określić poziom natężenia stresu w tym obszarze jako umiarkowany.

Zdecydowanie najwyższe natężenie stresu badani deklarowali w odniesieniu do możliwości zajścia w ciążę/spłodzenia potomstwa współżyjąc (średnia 6,89), przy czym u mężczyzn natężenie to było nieco silniejsze (średnia 7,00) niż u kobiet (średnia 6,85). Istotnym stresorem dla młodzieży był również pierwszy stosunek seksualny (średnia 6,12) oraz presja seksualna (średnia 5,22). W przypadku tego ostatniego stresora zauważono istotną statystycznie zależność. Kobiety odczuwały istotnie większe natężenie stresu związanego z presją seksualną niż badani mężczyźni $[Z=-2,082 ; p=0,037]$. Stresorami o najmniejszej sile dla badanych były pocałunki z partnerami (średnia 2,70). 


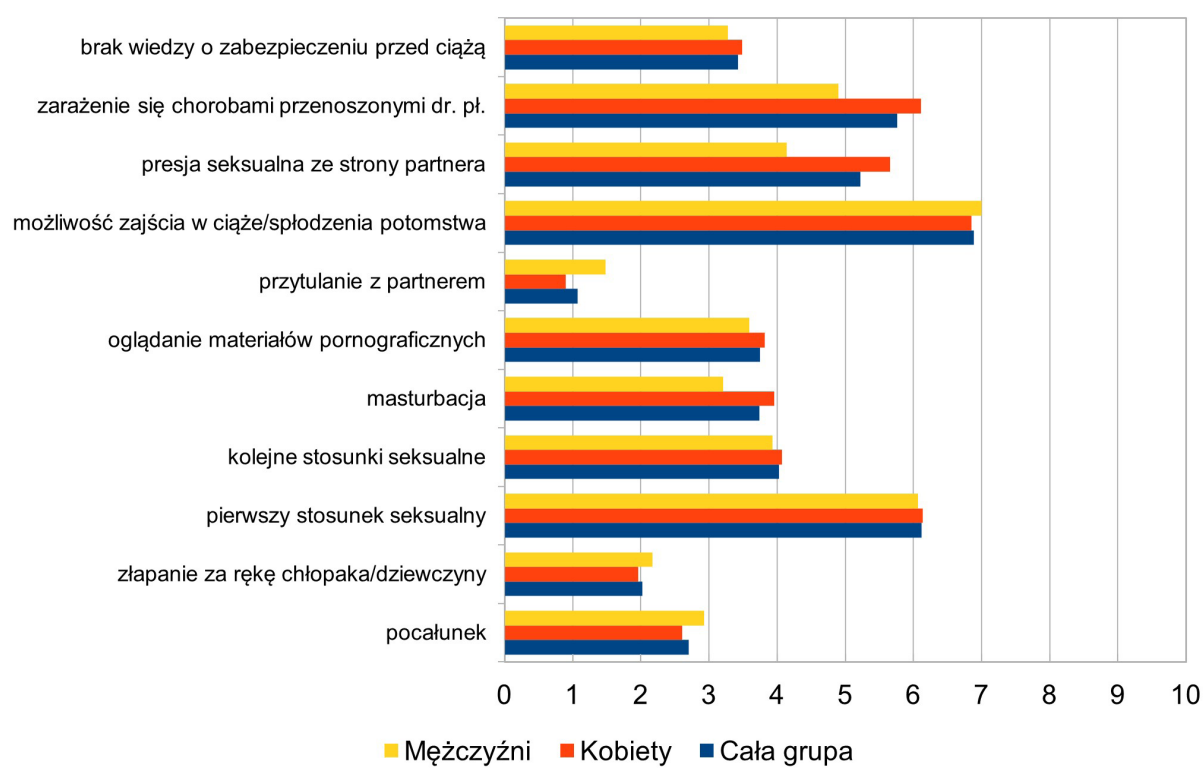

Ryc. 6. Średnie natężenie stresu badanej młodzieży w przestrzeni aktywności seksualnej

Średnie natężenie stresu $\mathrm{w}$ przestrzeni relacji z rówieśnikami wynosiło wśród badanej młodzieży 3,22. Mężczyźni przejawiali w tym zakresie nieznacznie wyższe średnie natężenie stresu $(2,40)$ niż kobiety $(2,22)$.

Stresorami o największej sile w tej przestrzeni życiowej badanych nastolatków były niepewność co do oceny własnej atrakcyjności przez partnera (średnia 5,0), obawa czy jest się akceptowanym w środowisku rówieśników (średnia 3,93) oraz porównywanie doświadczeń seksualnych w tym gronie (średnia 3,40). Stresorem o najmniejszej sile (średnia 2,16) była presja zachowania się w sposób oczekiwany przez grupę.

Średnie natężenie stresu $\mathrm{w}$ przestrzeni kultowej wyniosło $\mathrm{w}$ badanej grupie 3,26. Kobiety doświadczały w tym aspekcie silniejszego średniego natężenia stresu $(3,52)$ niż mężczyźni $(2,60)$.

Stresorem o największej sile $\mathrm{w}$ tym obszarze był dla badanych fakt, że współcześnie niewiele uwagi zwraca się na takie wartości, jak: wierność, odpowiedzialność czy miłość (średnia 4,92). Stresujące dla badanych było również to, że wiele uwagi zwraca się współcześnie na ciało, seksualność czy atrakcyjność fizyczną (średnia 4,24) oraz to, że we współczesnym świecie wszystko szybko ulega zmianie, np. przyjaźnie, sympatie czy moda (średnia 3,31 ). Stresorem o najmniejszej sile w tym obszarze była obecność seksualności w mediach (średnia 1,77). 


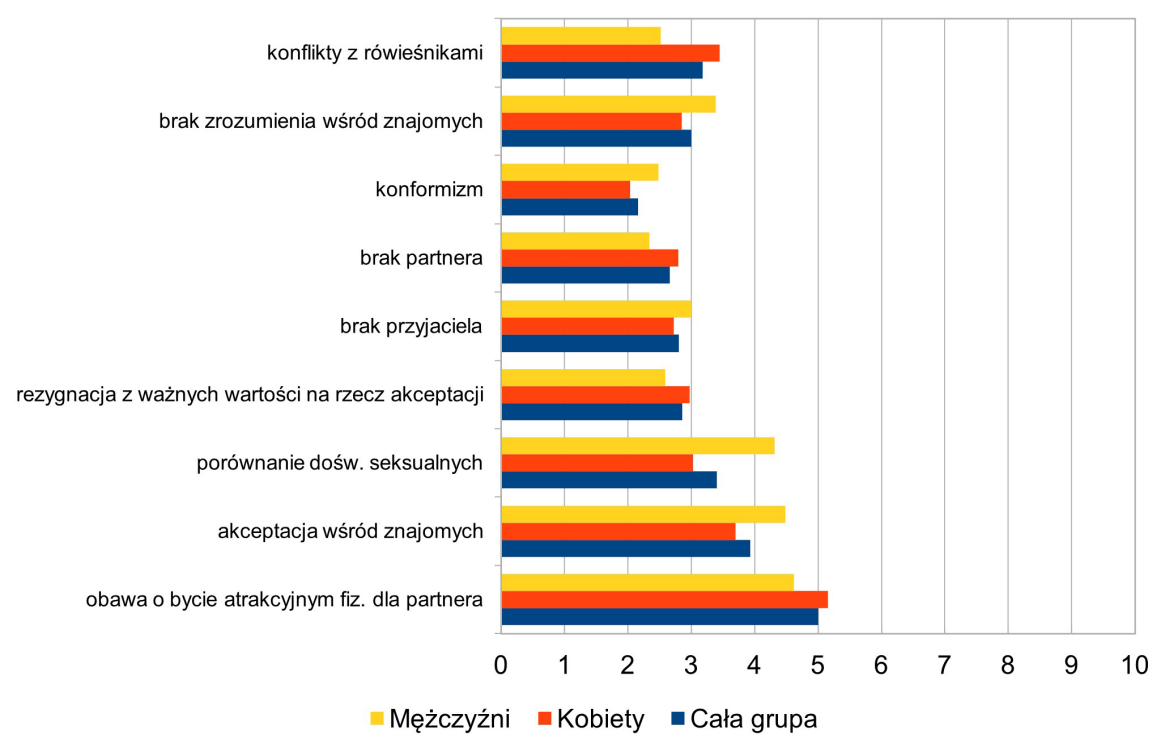

Ryc. 7. Średnie natężenie stresu badanej młodzieży w przestrzeni relacji z rówieśnikami (źródło: badania własne)

częstość kontaktów z rówieśnikami przez Internet

$$
\text { niemal nieograniczona możliwość wyboru }
$$

akcentowanie znaczenia atrakcyjności fiz.

niedocenianie uniwersalnych wartości

znaczna częstość i tempo zmian

kreaowany w mediach wizerunek mężczyzn

kreowany w mediach wizerunek kobiet

seksualizacja w mediach

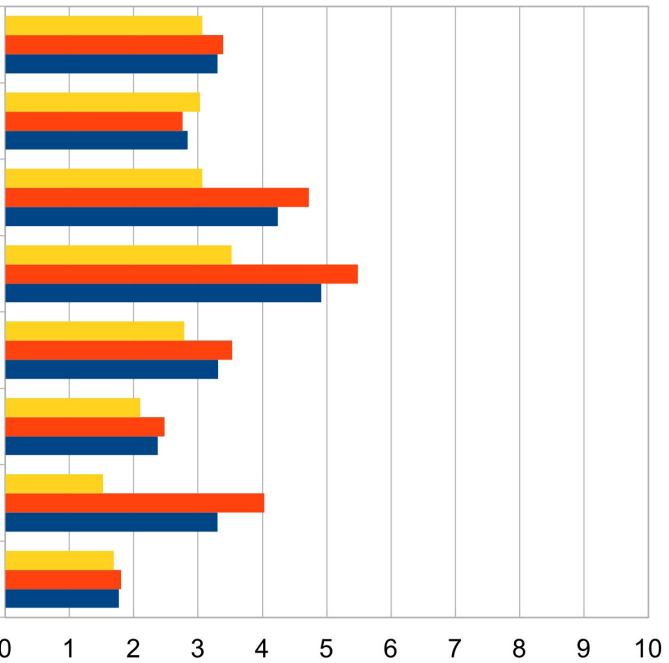

Mężczyźni $\quad$ Kobiety - Cała grupa

Ryc. 8. Średnie natężenie stresu badanej młodzieży w przestrzeni kulturowej (źródło: badania własne) 
W przestrzeni kulturowej $\mathrm{w}$ kontekście seksualności odkryto istotne statystycznie zależności pomiędzy płcią a odczuwanym natężeniem stresu. Respondentki odczuwały istotnie większe natężenie stresu związanego z przedstawianym $w$ mediach wizerunkiem kobiet niż mężczyźni $[Z=-3,845$; $\mathrm{p}<0,001$ ]. Znacznie silniejszy niż dla mężczyzn okazał się dla nich również stresor $\mathrm{w}$ postaci niedoceniania ponadczasowych wartości $[Z=-2,641$; $p=0,008]$ oraz koncentracja na cielesności i atrakcyjności fizycznej $[Z=-2,540$; $\mathrm{p}=0,011]$.

Interesujące są uzyskane wyniki dotyczącego tego, do kogo zwraca się badania młodzież w stresujących ją sytuacjach związanych z seksualnością. Najczęściej ich powiernikami byli przyjaciele (dla 62\% badanych). 39\% respondentów zwraca się w stresujących sytuacjach do mamy, a 31\% - do chłopaka/ dziewczyny. Żadna z badanych osób nie wskazała, że w kwestii seksualności zwróciłaby się do nauczyciela/wychowawcy, a tylko 3\% poprosiłoby o pomoc pedagoga lub psychologa szkolnego. Dane te ilustruje rycina 9 . Z jednej strony taki wynik może nie zaskakiwać; seksualność jako sfera intymna zarezerwowana jest w naturalny sposób dla osób najbliższych. W badanej grupie niemal dwukrotnie częściej niż rodzice (a właściwie matki, gdyż do ojców zwróciłoby się tylko 10\% badanych) są nimi przyjaciele. Z drugiej jednak strony, wzbudza pewien niepokój fakt, że specjaliści tacy jak psycholog i pedagog szkolny nie stanowią dla młodzieży źródła pomocy w doświadczanym stresie związanym z seksualnością.

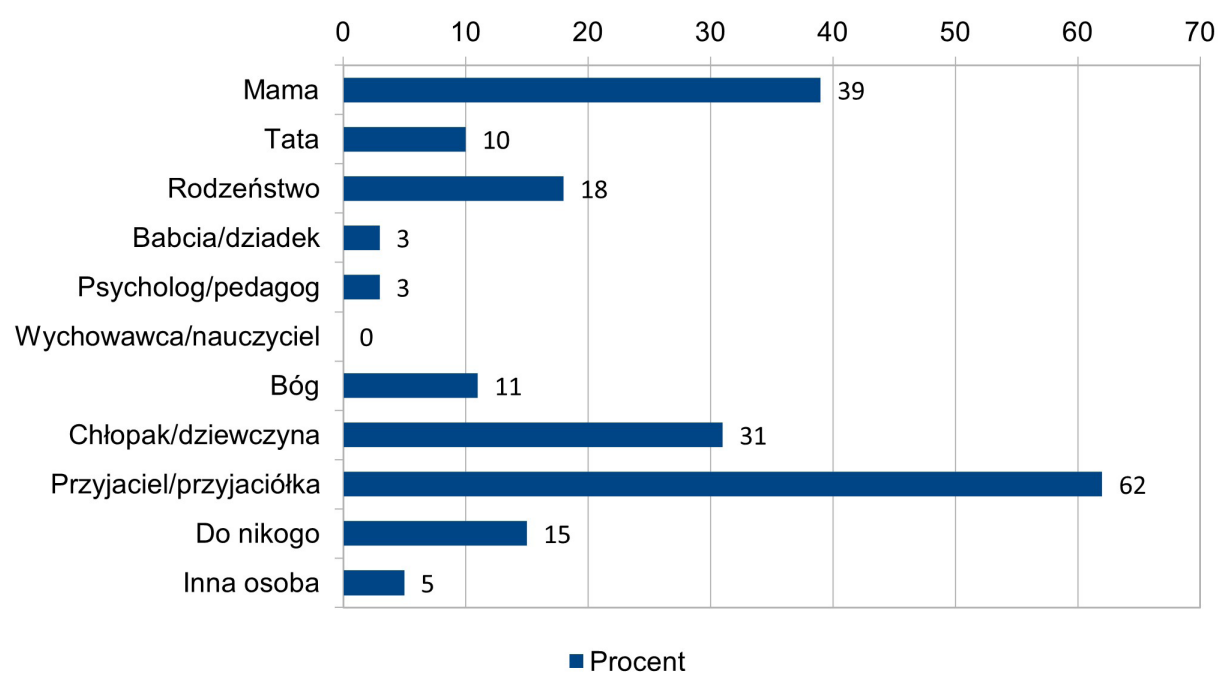

Ryc. 9. Osoby, do których młodzież zwraca się o pomoc w stresujących sytuacjach związanych z seksualnością 
Stwierdzono, że w badanej grupie występuje istotna statystycznie zależność pomiędzy podejmowaniem rozmów z partnerem/partnerką w związku z doświadczanym stresem a natężeniem jego odczuwania. Młodzież podejmująca rozmowy z sympatią cechuje się istotnie niższym natężeniem odczuwanego stresu. Jeszcze istotniejszy wydaje się wynik mówiący o tym, że osoby, które z nikim nie rozmawiają o doświadczanym stresie związanym z seksualnością, odczuwają istotnie większe natężenie stresu niż młodzież prowadząca takie rozmowy. Dane te przedstawiono w tabeli 4 . Wynik ten wskazuje na istotne znaczenie wsparcia młodzieży w doświadczaniu seksualności. Jego brak skutkuje wzrostem natężenia odczuwanego stresu.

Tabela 4

Zależność ogólnego natężenia stresu związanego z seksualnością od tego, z kim młodzież podejmuje rozmowy na ten temat

\begin{tabular}{|c|c|c|c|c|c|c|}
\hline \multicolumn{5}{|c|}{$\begin{array}{c}\text { Osoby, do których młodzież zwraca się o pomoc w stresujących } \\
\text { sytuacjach związanych z seksualnością }\end{array}$} & \multirow{2}{*}{\multicolumn{2}{|c|}{$\begin{array}{l}\text { Test } \\
\text { U Manna-Whitneya }\end{array}$}} \\
\hline & \multicolumn{2}{|c|}{ tak } & \multicolumn{2}{|c|}{ nie } & & \\
\hline & M & SD & $\mathrm{M}$ & SD & $\mathrm{Z}$ & $\mathrm{P}$ \\
\hline Mama & 3,13 & 2,27 & 3,21 & 2,95 & $-0,325$ & 0,745 \\
\hline Tata & 2,40 & 1,51 & 3,27 & 2,79 & $-0,720$ & 0,472 \\
\hline Rodzeństwo & 3,61 & 2,36 & 3,09 & 2,77 & $-1,192$ & 0,233 \\
\hline Babcia/dziadek & 3,67 & 1,15 & 3,16 & 2,73 & $-0,602$ & 0,547 \\
\hline $\begin{array}{l}\text { Psycholog/peda- } \\
\text { gog szkolny }\end{array}$ & 5,00 & 1,30 & 3,12 & 2,68 & $-0,240$ & 0,263 \\
\hline $\begin{array}{l}\text { Wychowawca/ } \\
\text { nauczyciel }\end{array}$ & - & 0 & 3,13 & 2,69 & - & - \\
\hline Bóg & 3,09 & 1,81 & 3,19 & 2,28 & $-0,128$ & 0,898 \\
\hline $\begin{array}{l}\text { Chłopak/dziew- } \\
\text { czyna }\end{array}$ & 2,23 & 2,43 & 3,61 & 2,71 & $-2,516$ & 0,012 \\
\hline $\begin{array}{l}\text { Przyjaciel/przyja- } \\
\text { ciółka }\end{array}$ & 3,32 & 2,65 & 2,95 & 2,78 & $-0,768$ & 0,443 \\
\hline $\begin{array}{l}\text { Do nikogo nie } \\
\text { zwracam się } \\
\text { o pomoc }\end{array}$ & 4,67 & 3,29 & 2,92 & 2,51 & $-1,975$ & 0,048 \\
\hline Inna osoba & 3,17 & 2,66 & 5,33 & 3,51 & $-1,231$ & 0,235 \\
\hline
\end{tabular}




\section{Podsumowanie}

W badaniach analizie poddano pięć obszarów życiowych adolescentów w kontekście ich seksualności. W większości natężenie odczuwanego stresu w nich można określić jako niskie. Jedynie w obszarze aktywności seksualnej miało ono charakter umiarkowany. W każdym obszarze wyłoniono najsilniejsze stresory. Nie mają one jednak jednorodnego charakteru. Próbując syntetycznie ująć uzyskane wyniki badań, można stwierdzić, że najmniej stresujące dla respondentów były te zjawiska, które dotyczą wyłącznie ich samych (z zakresu przestrzeni osobistej); stosunkowo silnie stresujące dla badanych były te współczesne zjawiska kulturowe, które literatura przedmiotu uznaje za niekorzystne z wychowawczego punktu widzenia, takie jak akcentowanie fizyczności i atrakcyjności seksualnej czy niedocenianie wartości wyższych, przy czym kobiety odczuwały silniejszy stres w tym zakresie niż badani mężczyźni. Stosunkowo silnie stresujące były dla respondentów relacje rówieśnicze, głównie w kontekście poczucia własnej wartości i akceptacji przez innych; ten wynik wydaje się zrozumiały w perspektywie rozwoju społecznego młodzieży. Najsilniejsze stresory zostały odnotowane w przestrzeni aktywności seksualnej. Z jednej strony młodzież stresuje to, co jest nieznane - pierwszy stosunek seksualny (kolejne były stresorami o znacznie mniejszym natężeniu), z drugiej zaś to, co - przynajmniej teoretycznie - podlega ich kontroli, czyli możliwość poczęcia nowego życia w wyniku aktywności seksualnej. W kontekście presji seksualnej kobiety odczuwały istotnie silniejsze natężenie stresu niż mężczyźni.

Ważny z wychowawczego punktu widzenia jest wynik wskazujący, że poziom stresu maleje $\mathrm{w}$ przypadku możliwości powierzenia go bliskiej osobie. Wsparcie społeczne w kontekście doświadczanej seksualności jest dla badanej młodzieży istotne. Najczęściej, wśród respondentów, uzyskiwane było od partnerów i przyjaciół. Uwagi wymaga fakt, że rodzice i specjaliści pracujący w szkole tylko w niewielkim zakresie wskazywani byli przez młodzież jako osoby, które mogą okazać się pomocne w kwestii zmniejszenia natężenia odczuwanego w związku z seksualnością stresu. Obszary, które w wyniku przeprowadzonych badań ujawniły się jako istotne w kwestii stresu związanego z seksualnością młodzieży, mogą z powodzeniem stać się elementem wychowania seksualnego, tak realizowanego w instytucjach oświatowych, jak i w przestrzeni życia rodzinnego.

$\mathrm{W}$ dalszym rozwoju interesujące poznawczo jest zbadanie, na reprezentatywnej grupie badawczej, jakie strategie przyjmują młodzi ludzie w celu radzenia sobie z odczuwanym stresem $\mathrm{w}$ kwestii seksualności oraz precyzyjnie, jakiego rodzaju wsparcia i od kogo oczekują w tym zakresie. 


\section{BIBLIOGRAFIA}

Bańka A., Społeczna psychologia środowiskowa, Wydawnictwo Scholar, Warszawa 2002.

Bee H., Psychologia rozwoju człowieka, przekł. A. Wojciechowski, Zysk i S-ka Wydawnictwo, Poznań 2004.

Beisert M., Seks twojego dziecka, Wydawnictwo K. Domke, Poznań 1991.

Beisert M., Trud dorastania seksualnego, [w:] Seksualność w cyklu życia człowieka, red. M. Beisert, Wydawnictwo Naukowe PWN, Warszawa 2011.

Brannon L., Psychologia rodzaju, Gdańskie Wydawnictwo Psychologiczne, Gdańsk 2002.

Czapiński J., Psychologia szczęścia, Wydawnictwo Scholar, Warszawa 2017.

Falewicz A., Psychologiczne koncepcje stresu i radzenia sobie, Studia Paradyskie, 2017, 27.

Giddens A., Przemiany intymności. Seksualność, miłość i erotyzm we wspótczesnych społeczeństwach, przekł. A. Szulżycka, Wydawnictwo Naukowe PWN, Warszawa 2006.

Grygorczuk A., Pojęcie stresu w medycynie i psychologii, Psychiatria, 2008, 5, 3.

Heszen-Niejodek I., Teoria stresu psychologicznego i radzenia sobie, [w:] Psychologia. Podręcznik akademicki, tom 3, red. J. Streulau, Gdańskie Wydawnictwo Psychologiczne, Gdańsk 2005.

Izdebski Z., Seksualność Polaków w dobie HIV/AIDS. Studium porównawcze 1997-2001-2005, Oficyna Wydawnicza Uniwersytetu Zielonogórskiego, Zielona Góra 2006.

Izdebski Z., Seksualność Polaków na początku XXI wieku. Studium badawcze, Wydawnictwo Uniwersytetu Jagiellońskiego, Kraków 2012.

Kucz E.A., Biologiczne aspekty seksualności człowieka, [w:] Seksualność w cyklu życia człowieka, red. M. Beisert, Wydawnictwo Naukowe PWN, Warszawa 2011.

Łapińska R., Żebrowska M., Wiek dorastania, [w:] Psychologia rozwojowa dzieci i młodzieży, red. M. Żebrowska, PWN, Warszawa 1966.

Marszałek L., Kulturowe uwarunkowania roli kobiety we wspótczesnym społeczeństwie, Seminare. Poszukiwania naukowe, 2008, 25.

Nowosielski K., Identyfikacja i rola ptciowa, [w:] Podstawy seksuologii, red. Z. Lew-Starowicz, V. Skrzypulec, Wydawnictwo Lekarskie PZWL, Warszawa 2010.

Obuchowska I., Jaczewski A., Rozwój erotyczny, Wydawnictwo Akademickie Żak, Warszawa 2002.

Okoń W., Nowy stownik pedagogiczny, Wydawnictwo Akademickie Żak, Warszawa 2007.

Ostruch-Kamińska J., Demokratyzacja relacji matżeńskich i rodzicielskich we wspótczesnych rodzinach, Roczniki Pedagogiczne, 2017, 4.

Smoter B., Tabu seksualne w rodzinie i szkole. W poszukiwaniu (nie)obecnych kategorii, Chowanna, 2013, 2.

Syrek E., Zdrowie psychospołeczne młodzieży czasu wspótczesnych przemian - konteksty kształtowania umiejętności życiowych, [w:] Młodzież w dobie przemian społeczno-kulturowych, red. K. Segiet, Wydawnictwo Naukowe UAM, Poznań 2015.

Strelau J. (red.), Psychologia. Podręcznik akademicki, tom 1, Gdańskie Wydawnictwo Psychologiczne, Gdańsk 2003.

Waszyńska K., Zielona-Jenek M., Zjawisko seksualizacji jako wyzwanie dla wspótczesnej edukacji, Studia Edukacyjne, 2016, 39. 